Received $\quad 05.10 .2016$ Reviewed 15.01.2017 Accepted 07.03.2017

A - study design

B - data collection

C - statistical analysis

D - data interpretation

$\mathbf{E}$ - manuscript preparation

F- literature search

\title{
Wadi Bounamoussa's waters quality in the north-east of Algeria: Statistical treatment of some physical and chemical parameters
}

\author{
Soumaya BOUSSAHA ${ }^{\text {ABCDEF } ه}$, Aziz LAIFA $^{\text {F }}$
}

Badji Mokhtar University, Annaba, Department of Biology, BP 12000, 23000 Annaba, Algeria; e-mail: soumayaboussaha@yahoo.fr, rlaifa23@yahoo.fr

For citation: Boussaha S., Laifa A. 2017. Wadi Bounamoussa's waters quality in the north-east of Algeria: Statistical treatment of some physical and chemical parameters. Journal of Water and Land Development. No. 34 p. $77-$ 83. DOI: 10.1515/jwld-2017-0040.

\begin{abstract}
Nowadays, problems with wastes constitute a danger increasingly important for the recipient environments. Indeed, the water is affected in an increasing way by mineral and organic materials from which some ones are pathogenic and thus dangerous for the ecosystem. It is in this context that the present study took place, it relates to the surface waters pollution of the Wadi Bounamoussa in the Algeria northeast. The study concerns the analysis of physical and chemical parameters of waters such as: temperature $(T)$, pH, electrical conductivity $(E C), \mathrm{Cl}^{-}$, chemical oxygen demand (COD), total absorbance colour (TAC), total hardness (TH), $\mathrm{PO}_{4}{ }^{3-}$, total phosphorus $\left(\mathrm{P}_{\text {tot }}\right)$ along the wadi in one year long survey (October 2013 to July 2014). Waters were sampled at ten study sites with a quarterly sampling.

In order to establish a relationship between various physical and chemical parameters and for a better assessment the anthropogenic effect on the Wadi Bounamoussa's water quality, we have processed a statistical treatment by means of the Principal Component Analysis (PCA).

PCA has revealed two gradients. The first reflects the eutrophication caused by chemical fertilizers used in agriculture and the intensive livestock farming development, while the second describes the resulting water mineralization of high rates of the $\mathrm{Cl}^{-}$and $E C$. Moreover, PCA has allowed discriminating the stations according to their physical and chemical data. This study has allowed us also to reveal the influence of seasonal variations.
\end{abstract}

Key words: eutrophication, mineralization, physicochemical, surface waters, Wadi Bounamoussa

\section{INTRODUCTION}

Water resource protection is one of the most essential concerns of any environmental policy, these resources being identified as paramount for the future [ATTOUI et al. 2016]. The deterioration of the water springs quality resulted of human activity constitutes as important a threat as that associated to the quantitative imbalance. In Algeria, population growth accompanied by a rapid urbanization cause numerous perturbations for natural environments [KHERIFI 2016]. In parallel, the industrialization, the unsustainable use of fertilizers and pesticides, and the public awareness lack of environmental protection lead to an ecosystem imbalance and generate pollutants that can affect the receptor aquatic environement's physical and chemical and biological quality (lake, river, marsh, etc.), but also alter the water uses (water abstraction, swimming, fishing, etc.) [HARRAT, ACHOUR 2010].

The lakes and reservoirs's eutrophication count from among the water pollution types that are the most common [SEMAOUNE 2008]. It is a very slow natural process by which water bodies receive a large amount of nutrients, including the phosphorus and the 
nitrogen that stimulate the algae and aquatic plants growth. In particular, the increased use of chemical fertilizers, the intensive livestock farming development in the agriculture, the industrial effluents and domestic wastewater which have accelerated in many water courses and lakes by their significant inputs of phosphored and nitrogen materials in these mediums [KHELLOU 2012].

The objective of this study is to assess the Wadi Bounamoussa's surface waters quality which is one of the important water courses in the north-eastern Algerian region. We have adopted a physical and chemical approach by describing the various parameters's evolution in this wadi waters.

\section{MATERIALS AND METHOD}

\section{STUDY AREA}

Wadi Bounamoussa takes its birth in height's Bouhadjar town by the confluence of the Wadi El-Kebir and Wadi Bouhadjar at the level of the El-Taref city [LABAR 2003]. It is one of the main water courses situated in the El-Taref town. Originating from the territorial division of 1984, the El-Taref town is situated in the Algerian's extreme north-east and extends on an area of $2.891 .63 \mathrm{~km}^{2}$. It has a $90 \mathrm{~km}$ of coastline (Fig. 1). This wadi is localised into El-Taref and Annaba cities, which $90 \%$ is localised in El-Taref city with its communes of Besbes, Echatt, Zerizer, Asfour, Ben M'Hidi and Chebaita Mokhtar and the $10 \%$ for Annaba city restrained at both communes El-Hadjar, El-Bouni only [KHEIREDDINE 2012].

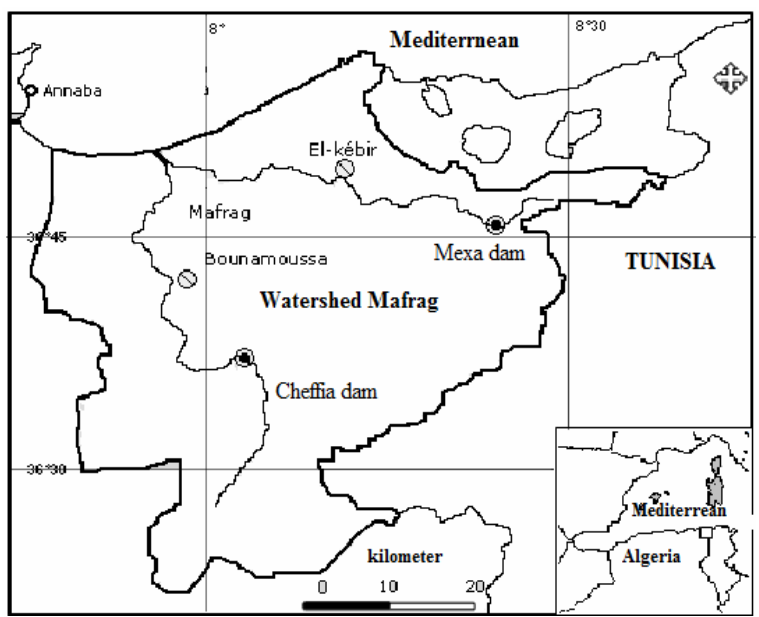

Fig. 1. The Wadi Bounamoussa watershed's geographical location; source: HARIDI et al. [2012]

In the north, the plain is limited mainly by the Djebel Boukerma which culminates at $356 \mathrm{~m}$, in the South by Koudiat El-Kriane with $476 \mathrm{~m}$ of altitude, in the East by Mechtet Abdelkader $509 \mathrm{~m}$ of altitude while in the West by Kef Ed Deba reaching $556 \mathrm{~m}$ of altitude [BOUKHNOUNA 2008].

The various sources of potential pollution recensed in the study zone (domestic wastewaters, in- dustrial and run-off and leaching agricultural), orientated us towards the ten stations choice (S01 to S10) distributed along the Wadi Bounamoussa (Fig. 2); have been retained such that they are accessible and reflecting the real characteristics of the Wadi Bounamoussa's surface waters in the study zone.

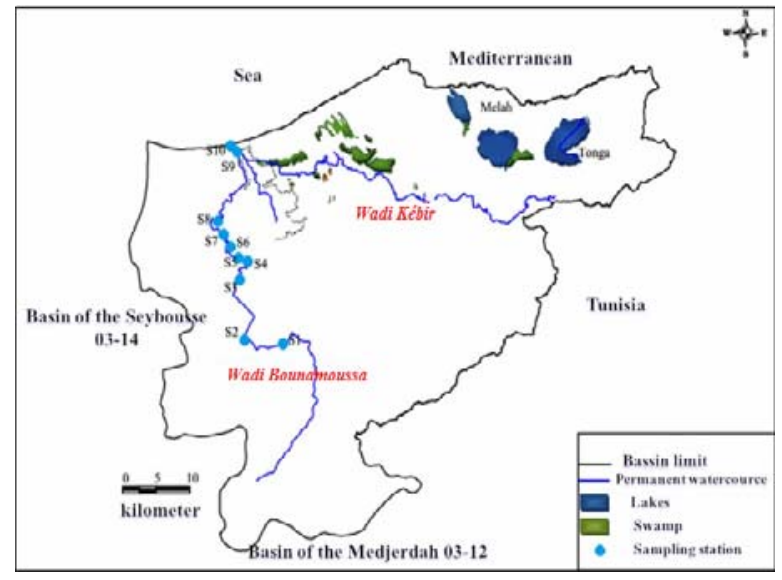

Fig. 2. Location Map of the waters sampling stations in the Wadi Bounamoussa; source: own elaboration

The coordinates, the various sampling points in these stations are indicated by a (Global Positioning System GPS) device (Tab. 1).

Table 1. Sampling stations location in the Wadi Bounamoussa

\begin{tabular}{|c|c|c|c|c|}
\hline \multicolumn{2}{|c|}{ The stations } & \multicolumn{2}{|c|}{ Geographical coordinates } & \multirow[b]{2}{*}{ Region } \\
\hline $\begin{array}{l}\text { low } \\
\text { waters }\end{array}$ & $\begin{array}{l}\text { high } \\
\text { waters }\end{array}$ & latitude & longitude & \\
\hline S01 & $\mathrm{S} 1{ }^{\prime}$ & N $36^{\circ} 36^{\prime} 9.83^{\prime \prime}$ & E 8²4’72”' & Tofaha \\
\hline $\mathrm{S} 02$ & S 2' & N 36³9'23.16" & E 757’42.50" & Bouzitouna \\
\hline S03 & S 3, & N 36⒋ ${ }^{\prime} 11.82^{\prime \prime}$ & E 757’36.12”' & Skoufi \\
\hline S04 & S 4 , & N 36 $46^{\circ} 30.92^{\prime \prime}$ & E 756’30.1” & $\begin{array}{c}\text { Nchayma } \\
\text { (farm) }\end{array}$ \\
\hline S05 & S 5, & N 36 $46^{\circ} 44.31^{\prime \prime}$ & E 757’29.93”' & $\begin{array}{l}\text { Nchayma } \\
\text { (graveyard) }\end{array}$ \\
\hline S06 & S 6 ' & N 36³ $43^{\prime} 35.13^{\prime \prime}$ & E 756’39.63" & Pont de Zerizer \\
\hline S07 & S 7' & N 364 $37^{\prime} 37.96^{\prime \prime}$ & E 750’12.27’' & Bordj Semar \\
\hline S08 & S 8 , & $\mathrm{N} 36^{\circ} 45^{\prime} 25.12^{\prime \prime}$ & E 755’23.69”' & Ben-M'hidi \\
\hline S09 & S 9' & N 365ㅇ'28.10" & E 7 $7^{\circ} 57^{\prime} 19.58^{\prime \prime}$ & Griâte \\
\hline S10 & S 10' & N 3650’54.2”' & E 756’40.69" & Battah \\
\hline
\end{tabular}

Source: own elaboration.

\section{METHODS}

Water sampling along the Wadi Bounamossa (Fig. 2), on ten stations, during the hydrological year (2013/2014), have allowed to make four measurements campaigns: (October 2013, January 2014, April 2014 and July 2014).

The water samples were taken and introduced into polyethylene bottles previously rinsed with the station water. They have been then stored at $4^{\circ} \mathrm{C}$ during transport them to the laboratory where they were carried out within next 24 hours of sampling.

The parameters recorded in situ are: $\mathrm{pH}$ (hydrogen potential), temperature $(T)$ and electrical conduc- 
tivity $(E C)$, the measurement device is a multiparameter (HANNA instruments HI 9828). The determination of the chemical oxygen demand (COD) by the AFNOR method (T90-101) [RODIER et al. 2009]. The chloride ions's analyzes (Mohr volumetric's method), alkali concentration and total hardness (volumetric method) [RODIER et al. 2009].

The ortho-phosphate's dosing is determined by the in acid medium colorimetric's method [RODIER 2009]. An acid mineralization is used for the total phosphorus dosing [RoDIER et al. 2009].

\section{RESULTS AND DISCUSSION}

In order to establish a relationship between the different physical and chemical parameters and for better assess the anthropogenic activities effect on the Wadi Bounamoussa's water quality, a statistical treatment by mean of PCA method "The Principal
Component Analysis" was applied for the whole parameters.

The PCA is a data analysis tool that explains the correlations structure or covariance using the original data's linear combinations. Its use allows us to reduce and interpret data in a reduced space. The PCA's object is to present, in graphic form, the information maximum contained in a data table, based on the double projection principle on the factorial axes.

Nine variables temperature $(T), \mathrm{pH}$, electrical conductivity $(E C), \mathrm{Cl}^{-}$, chemical oxygen demand (COD), total absorbance colour (TAC), total hardness $(\mathrm{TH}), \mathrm{PO}_{4}{ }^{3-}$, total phosphorus $\left(\mathrm{P}_{\text {tot }}\right)$ and ten individuals from S01 to S10 used by PCA treatment, over one year of monitoring during the $(2013 / 2014)$ period.

The PCA results on a data matrix; which consisting of ten stations during the wet campaign (high water mark) and ten stations also during the dry campaign (low water levels).

Table 2. The physical and chemical parameters seasonal variation of the site studied

\begin{tabular}{|c|c|c|c|c|c|c|c|c|c|c|}
\hline \multirow{2}{*}{\multicolumn{2}{|c|}{ Stations }} & \multirow{3}{*}{$\begin{array}{c}\mathrm{pH} \\
7.345\end{array}$} & \multirow{3}{*}{$\begin{array}{c}E C \\
\mu \mathrm{S} \cdot \mathrm{cm}^{-1} \\
450.5\end{array}$} & \multirow{3}{*}{$\begin{array}{c}T \\
{ }^{\circ} \mathrm{C} \\
26.5\end{array}$} & \multirow{3}{*}{$\frac{\begin{array}{c}\mathrm{COD} \\
\mathrm{mg} \cdot \mathrm{dm}^{-3}\end{array}}{610.0}$} & \multirow{3}{*}{$\begin{array}{l}\begin{array}{l}\mathrm{Cl}^{-} \\
\text {ppm }\end{array} \\
27.465\end{array}$} & \multirow{3}{*}{$\begin{array}{c}\mathrm{PO}_{4}{ }^{3-} \\
\mathrm{mg} \cdot \mathrm{dm}^{-3}\end{array}$} & \multirow{3}{*}{$\begin{array}{c}\mathrm{P}_{\text {tot }} \\
\mathrm{mg} \mathrm{PO}_{4}^{-3} \cdot \mathrm{dm}^{-3} \\
1.805\end{array}$} & \multirow{2}{*}{\multicolumn{2}{|c|}{ French degree $\left({ }^{\circ} \mathrm{F}\right)$}} \\
\hline & & & & & & & & & & \\
\hline \multirow{10}{*}{ 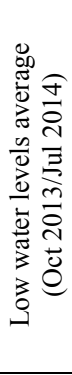 } & S01 & & & & & & & & 16.90 & 14.00 \\
\hline & S02 & 7.620 & 466.0 & 26.0 & 860.0 & 40.545 & 0.260 & 1.460 & 25.70 & 15.50 \\
\hline & S03 & 7.185 & 561.0 & 24.0 & 697.5 & 58.860 & 0.755 & 2.020 & 27.37 & 21.70 \\
\hline & S04 & 7.055 & 773.5 & 25.0 & 670.0 & 165.680 & 0.460 & 1.455 & 37.10 & 16.40 \\
\hline & S05 & 7.075 & 759.5 & 26.0 & 615.0 & 130.800 & 1.255 & 1.830 & 45.16 & 26.50 \\
\hline & S06 & 7.470 & 555.5 & 26.0 & 115.0 & 131.670 & 0.480 & 1.340 & 41.50 & 21.85 \\
\hline & S07 & 7.165 & 826.5 & 26.0 & 56.0 & 175.130 & 0.845 & 1.765 & 44.50 & 28.00 \\
\hline & S08 & 7.445 & 1180.0 & 25.0 & 642.5 & 142.975 & 0.795 & 1.925 & 38.80 & 12.00 \\
\hline & S09 & 7.160 & 5120.0 & 26.0 & 705.0 & 5232.000 & 0.360 & 1.145 & 33.00 & 30.40 \\
\hline & S10 & 7.340 & 7200.0 & 25.0 & 675.0 & 3544.520 & 0.370 & 1.185 & 28.15 & 36.25 \\
\hline \multirow{10}{*}{ 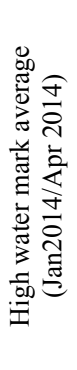 } & S01' & 7.640 & 340.0 & 15.5 & 104.0 & 37.060 & 0.255 & 1.815 & 30.00 & 21.00 \\
\hline & S02' & 7.730 & 429.0 & 16.5 & 97.0 & 69.975 & 0.255 & 1.895 & 16.50 & 28.00 \\
\hline & S03' & 7.370 & 392.0 & 15.5 & 158.5 & 35.530 & 0.895 & 2.250 & 30.00 & 16.60 \\
\hline & S04' & 7.510 & 570.5 & 16.5 & 78.0 & 97.225 & 0.200 & 1.525 & 42.50 & 31.00 \\
\hline & S05' & 7.005 & 395.5 & 16.5 & 168.0 & 220.320 & 0.165 & 1.605 & 73.50 & 46.50 \\
\hline & S06' & 7.380 & 1013.0 & 16.0 & 178.5 & 48.610 & 0.455 & 1.975 & 26.00 & 31.80 \\
\hline & S07' & 7.430 & 1079.5 & 15.5 & 49.5 & 126.440 & 0.385 & 1.840 & 40.00 & 31.30 \\
\hline & S08' & 7.455 & 875.5 & 17.0 & 39.0 & 63.220 & 0.315 & 2.585 & 27.50 & 20.50 \\
\hline & S09' & 7.410 & 2335.0 & 17.0 & 146.0 & 621.300 & 0.285 & 1.650 & 46.50 & 18.50 \\
\hline & S10' & 7.505 & 2625.0 & 17.5 & 119.5 & 745.560 & 0.345 & 1.310 & 53.50 & 23.00 \\
\hline
\end{tabular}

Explanations: $E C=$ electrical conductivity, $T=$ temperature, $\mathrm{COD}=$ chemical oxygen demand, $\mathrm{TH}=$ total hardness, $\mathrm{TAC}=$ total absorbance colour.

Source: own study.

\section{LOW WATER LEVELS PERIOD}

The study shows significant positive correlations between organic pollution parameters $\left(\mathrm{P}_{\text {tot }}, \mathrm{PO}_{4}^{-3}\right)$ where this ratio exceeds $66 \%(r>0.66)$, and between the mineral pollution parameters such as chlorides and electrical conductivity $(r>0.90)$ - Table 3 .

At the same time, we note a significant negative correlation between the chlorides and the organic pollution parameter $\mathrm{rC}^{-} / \mathrm{P}_{\text {tot }}=0.70$.

A highly significant negative correlation was observed between $\mathrm{pH}$ and orthophosphates with $r \geq 0.5$.

The correlation circle observation shown in (Fig. 3) formed by the F1-F2 axes, thus the factorial design analysis F1-F2 axes shows that over $63.68 \%$ of the information are illustrated. The $\mathrm{F} 1$ axis has a variance of $37.74 \%$ and the $\mathrm{F} 2$ axis has $25.94 \%$. The $\mathrm{F} 1$ axis is expressed by the electrical conductivity, the chloride ions and the complete alkali concentration in the positive pole but total phosphorus and the orthophosphate in the negative pole. The F2 axis consists of the total hardness in the positive pole, whereas the $\mathrm{pH}$ and the chemical oxygen demand oppose this parameter with a negative correlation coefficient. Regarding the variables representation, this graph highlights two large groupings of the parameters studied in the water points, it is seen that taking into account the mineral and organic variables. 
Table 3. The physical and chemical parameters correlation matrix (low water levels period)

\begin{tabular}{|l|c|c|c|c|c|c|c|c|c|}
\hline Parameter & $\mathrm{pH}$ & $E C$ & $T$ & $\mathrm{COD}$ & $\mathrm{Cl}^{-}$ & $\mathrm{PO}_{4}{ }^{3-}$ & $\mathrm{P}_{\text {tot }}$ & $\mathrm{TH}$ & $\mathrm{TAC}$ \\
\hline $\mathrm{pH}$ & 1 & - & - & - & - & - & - & - & - \\
\hline$E C$ & -0.070 & 1 & - & - & - & - & - & - & - \\
\hline$T$ & 0.194 & -0.123 & 1 & - & - & - & - & - & - \\
\hline $\mathrm{COD}$ & 0.073 & 0.231 & -0.298 & 1 & - & - & - & - & - \\
\hline $\mathrm{Cl}^{-}$ & -0.160 & $\mathbf{0 . 9 0 8}$ & 0.030 & 0.237 & 1 & - & - & - & - \\
\hline $\mathrm{PO}_{4}{ }^{3-}$ & $-\mathbf{0 . 4 8 2}$ & -0.345 & -0.116 & -0.255 & -0.380 & 1 & - & - & - \\
\hline $\mathrm{P}_{\text {tot }}$ & -0.138 & $-\mathbf{0 . 6 7 1}$ & -0.247 & -0.042 & $-\mathbf{0 . 7 0 9}$ & $\mathbf{0 . 6 6 8}$ & 1 & - & - \\
\hline $\mathrm{TH}$ & -0.354 & -0.152 & 0.029 & $-\mathbf{0 . 5 6 7}$ & -0.130 & $\mathbf{0 . 6 3 9}$ & 0.046 & 1 & - \\
\hline TAC & -0.366 & $\mathbf{0 . 7 4 8}$ & -0.016 & -0.197 & $\mathbf{0 . 6 8 7}$ & 0.079 & $-\mathbf{0 . 4 8 7}$ & 0.225 & 1 \\
\hline
\end{tabular}

Explanations as at Tab. 2. Source: own study.

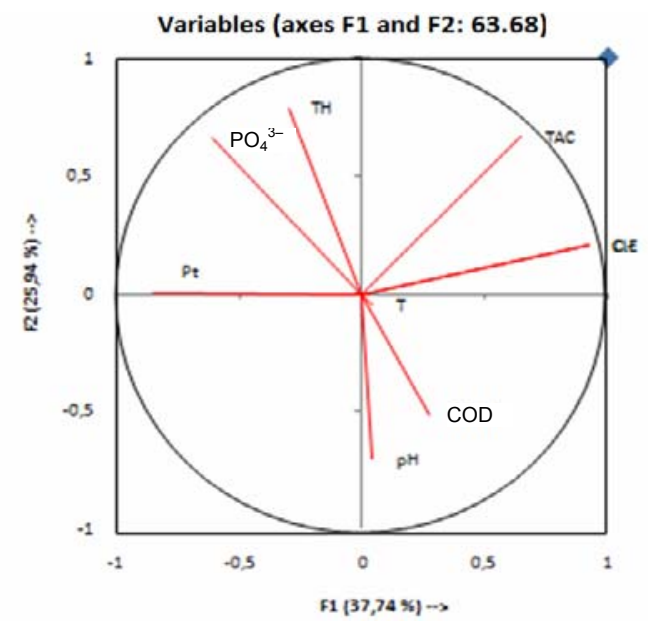

Fig. 3. Variables projection in the space of the axes F1 and F2 in a low water levels period; source: own study

The first grouping that takes into account " $\mathrm{Cl}^{-}$, $E C$, TAC". This important correlation shows that these elements participate majorly in the water mineralization. These ions are responsible for mineralization in the study zone's different waters. The mineralization origin would be sea water on the one hand and on the other hand the evaporitic geological facies of gypsum on the other.

The second grouping contains $\left(\mathrm{PO}_{4}{ }^{3-}, \mathrm{P}_{\text {tot }}\right)$ shows an anthropogenic pollution from municipal discharges. These releases come from various domestic uses of water and agricultural activities through the agricultural crops's spreading (fertilizers and pesticides) and the animal farming. A trioazote, phosphate and potassium (NPK) is all these product's basis.

The individuals graphical representation (Fig. 4) also allows to distinguish three groups. The first group formed by the variables account the station (S05 and S07) which represents the point whose water quality is loaded with $\mathrm{PO}_{4}{ }^{3-}$ and $\mathrm{TH}$. These two stations are represented by the Zerizer village's raw wastewater, the high contents in orthophosphate, shows the urban and agricultural pollution in the waters and the organic matter decomposition that favours the bacteria and algae proliferation [ILNICKI 2014]. The second group contains the stations of S01 to S03 and S08 which represents the points whose waters are weakly mineralized with a high content in the whole total phosphorus. Thus indicate the wadi's waters pol- lution of the agricultural origin caused by the direct discharges of the polluting substances of the urban activities. The third group comprises the stations S09 and S10 which represents the Wadi Bounamoussa's outfalls in the estuarine zone characterized by a strong mineralization expressed by values of very high electrical conductivity and abundant chloride ions. This group of sampling stations therefore reflects the influence of sea water on the physical and chemical quality of the Wadi Bounamoussa's final sequence.

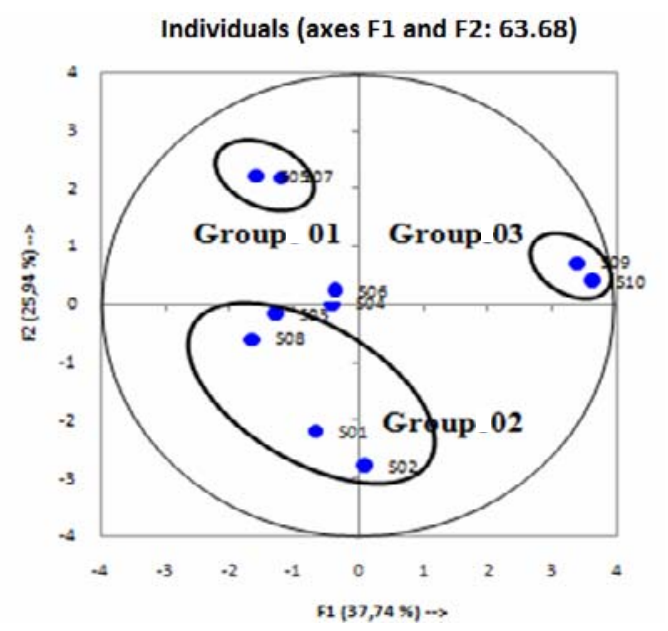

Fig. 4. The stations graphic representation on the factorial design F1, F2 in a low water levels period; source: own study

\section{HIGH WATER MARK PERIOD}

The examination shows a very significant positive correlation ratios, in particular between parameters of mineral pollution, electrical conductivity and chlorides, where this ratio exceeds $92 \%(r>0.92)$, $\mathrm{rTH} / \mathrm{TAC}=0.53-$ Table 4 . And between the organic pollution parameters such as $\mathrm{rPO}_{4}^{-3} / \mathrm{P}_{\text {tot }}=0.45$.

A highly significant negative correlation was observed between (COD, TH, TAC and $\mathrm{pH}$ ).

It is also pointed out that the correlation coefficient $\mathrm{rP}_{\text {tot }} / \mathrm{Cl}^{-}=-0.62$.

The correlation circle formed by the F1 and F2 axes in (Fig. 5) giving $64.88 \%$ of the total information, shows that: the $\mathrm{F} 1$ axis has a $39.47 \%$ variance presenting only the variables with organic character, $\mathrm{P}_{\text {tot }}$ and $\mathrm{PO}_{4}{ }^{3-}$, with the presence of $\mathrm{Cl}^{-}$, the conducti- 
Table 4. Correlation matrix of the physical and chemical parameters (high water mark period)

\begin{tabular}{|c|c|c|c|c|c|c|c|c|c|}
\hline Parameter & $\mathrm{pH}$ & $E C$ & $T$ & $\mathrm{COD}$ & $\mathrm{Cl}^{-}$ & $\mathrm{PO}_{4}^{3-}$ & $\mathrm{P}_{\text {tot }}$ & $\mathrm{TH}$ & TAC \\
\hline $\mathrm{pH}$ & 1 & - & - & - & - & - & - & - & - \\
\hline$E C$ & 0.028 & 1 & - & - & - & - & - & - & - \\
\hline$T$ & -0.022 & 0.650 & 1 & - & - & - & - & - & - \\
\hline COD & -0.484 & 0.079 & -0.059 & 1 & - & - & - & - & - \\
\hline $\mathrm{Cl}^{-}$ & -0.099 & 0.922 & 0.711 & 0.202 & 1 & - & - & - & - \\
\hline $\mathrm{PO}_{4}^{3-}$ & -0.057 & -0.081 & -0.440 & 0.298 & -0.195 & 1 & - & - & - \\
\hline $\mathrm{P}_{\text {tot }}$ & 0.058 & -0.437 & -0.297 & -0.247 & -0.624 & 0.457 & 1 & - & - \\
\hline $\mathrm{TH}$ & -0.743 & 0.301 & 0.337 & 0.288 & 0.542 & -0.334 & -0.612 & 1 & - \\
\hline TAC & -0.573 & -0.309 & -0.036 & 0.182 & -0.162 & -0.476 & -0.352 & 0.535 & 1 \\
\hline
\end{tabular}

Explanations as at Tab. 2.

Source: own study.

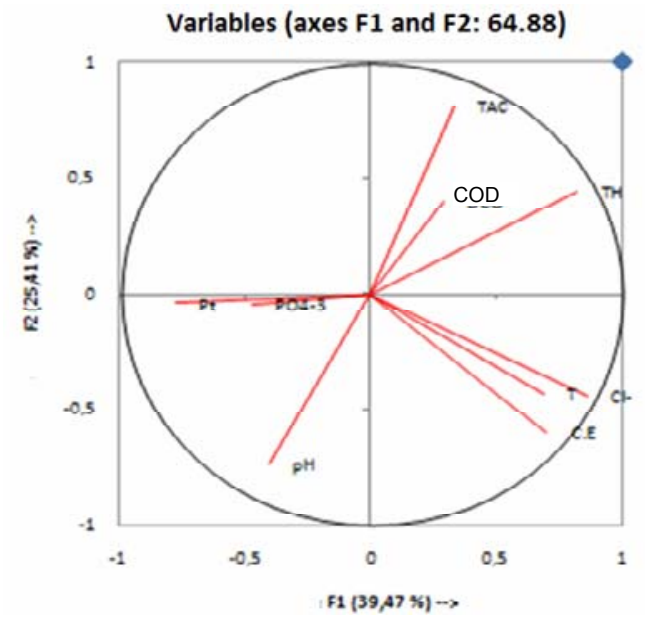

Fig. 5. The stations graphic representation on the factorial design F1, F2 in a high water mark period; source: own study

vity and temperature, are detached on the positive part of F1 axis, in opposite side to the variables's organic pollution. This axis then defines a mineralization gradient and organic pollution, which affects the aquatic environment. While the F2 axis has a variance of $25.41 \%$. It is constituted by the complete alkali concentration and the chemical demand of the oxygen in the positive pole contrariwise by the $\mathrm{pH}$ is in the negative pole.

Individuals's graphical representation (Fig. 6) allows to distinguish two groups also.

The first group includes the stations ( $\mathrm{S} 01$ ', S02', S03', S04', S06', S07', S08'). This group characterizes the Wadi Bounamoussa's water during the high water mark season where a high organic pollution would cause high levels contents of both ions orthophosphate and total phosphorus; a slightly lower $\mathrm{pH}$ compared to the other groups. This organic pollution caused by increased use of chemical fertilizers also by the waters that flow directly into the wadi without sanitation. The second group comprises the stations (S09' and S10') which represent the points whose waters are highly mineralized. This is reflected by the good positive correlation between the $\mathrm{Cl}^{-}$ion concentrations and the electrical conductivity values in these two stations.

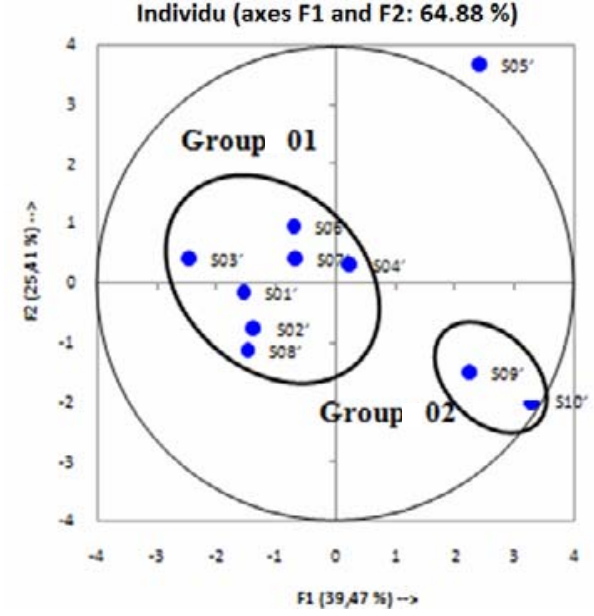

Fig. 6. The stations graphic representation on the factorial design $\mathrm{F} 1, \mathrm{~F} 2$ in a high water mark period; source: own study

\section{HIGH WATER MARK AND LOW WATER LEVELS PERIOD}

The correlation matrix examination between variables revealed the existing correlation between the parameters $\mathrm{Cl}^{-}$and $E C$ is an obvious correlation. On the other hand we interest by the negative correlation between $\mathrm{Cl}^{-}$and $\mathrm{P}_{\text {tot }}$.

During high water mark the low chloride content (Fig. 8) could be explained by dilution by rainwater's. Since chloride ions have a high concentration in low water levels periods (Fig. 7), where the sources of this element are essentially constituted by wastewater discharge, notably urban waste [BENRABAH et al. 2016], at the level of our stations. This pollution is rather anthropogenic and would result from the presence of domestic wastes, phytosanitary products used in agriculture and animal excrement in the wadi edge. At the same time, a high concentration of total phosphorus is noted during the high waters mark (Fig. 8) which exceeds the Algerian standard of the National Agency for Hydraulic Resources (ANHR) of surface waters $\left(\leq 1 \mathrm{mg} \cdot \mathrm{dm}^{-3}\right)$. The high content of total phosphorus cause the eutrophication phenomenon which leads to ecosystem disturbance by the algae appearance such as Cyanophyceae with a frequency of $(44.03 \%)$, Eu- 


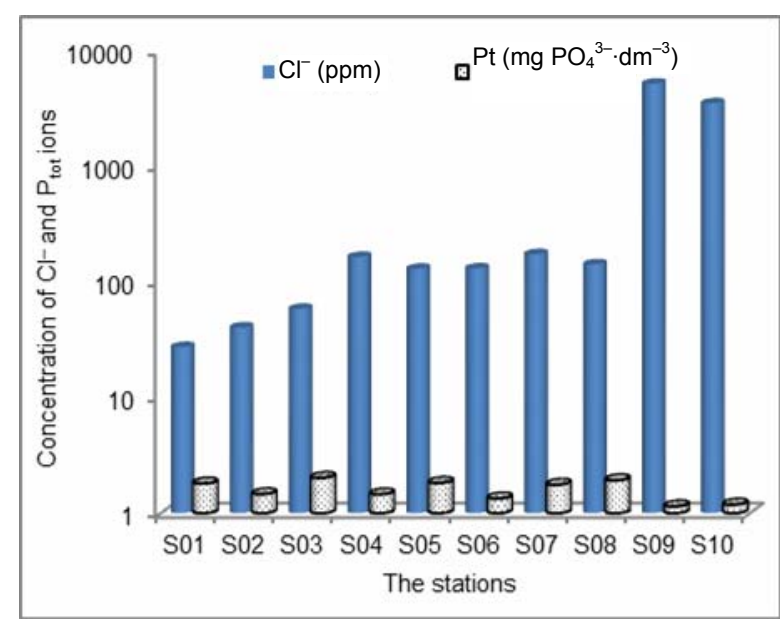

Fig. 7. Spatio-temporal variation of chloride ion and total phosphorus concentrations in the Wadi Bounamoussa's waters in low water levels period; source: own study

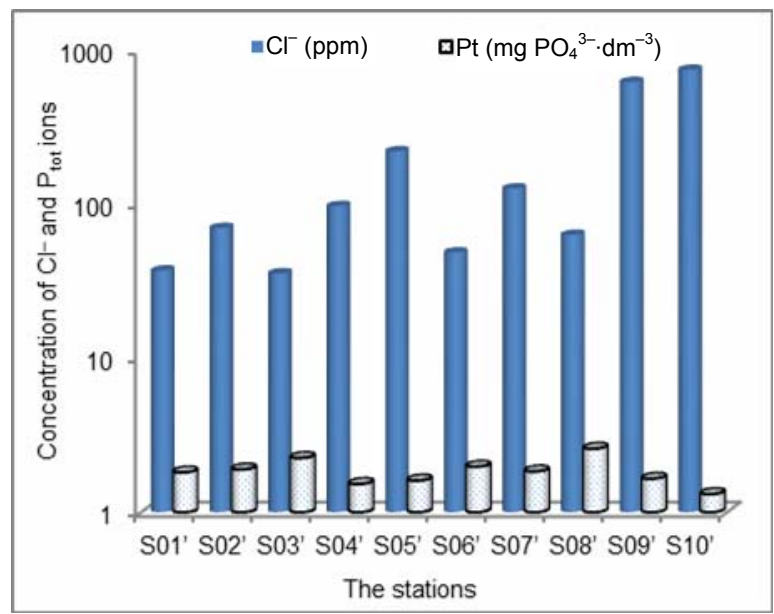

Fig. 8. Spatio-temporal variation of chloride ion and total phosphorus concentrations in the Wadi Bounamoussa's waters in high mark period; source: own study

Table 5. Correlation matrix of the physical and chemical parameters (high water mark and low water levels period)

\begin{tabular}{|l|c|c|c|c|c|c|c|c|c|}
\hline Parameter & $\mathrm{pH}$ & $E C$ & $T$ & $\mathrm{COD}$ & $\mathrm{Cl}^{-}$ & $\mathrm{PO}_{4}{ }^{3-}$ & $\mathrm{P}_{\text {tot }}$ & $\mathrm{TH}$ & $\mathrm{TAC}$ \\
\hline $\mathrm{pH}$ & 1 & - & - & - & - & - & - & - & - \\
\hline$E C$ & -0.126 & 1 & - & - & - & - & - & - & - \\
\hline$T$ & -0.384 & 0.233 & 1 & - & - & - & - & - & - \\
\hline $\mathrm{COD}$ & -0.322 & 0.310 & $\mathbf{0 . 7 5 3}$ & 1 & - & - & - & - & - \\
\hline $\mathrm{Cl}^{-}$ & -0.222 & $\mathbf{0 . 8 9 6}$ & 0.299 & 0.367 & 1 & - & - & - & - \\
\hline $\mathrm{PO}_{4}{ }^{3-}$ & $-\mathbf{0 . 4 2 4}$ & -0.150 & 0.401 & 0.244 & -0.154 & 1 & - & - & - \\
\hline $\mathrm{P}_{\text {tot }}$ & 0.118 & $\mathbf{- 0 . 5 5 5}$ & -0.396 & -0.319 & $-\mathbf{0 . 5 7 1}$ & 0.306 & 1 & - & - \\
\hline $\mathrm{TH}$ & $-\mathbf{0 . 4 5 2}$ & -0.027 & -0.152 & -0.284 & -0.051 & 0.003 & -0.291 & 1 & - \\
\hline TAC & -0.310 & 0.307 & -0.275 & -0.277 & 0.322 & -0.254 & -0.268 & $\mathbf{0 . 4 5 0}$ & 1 \\
\hline
\end{tabular}

Explanations as at Tab. 2.

Source: own study.

glenophyceae (41.61\%), Diatomophyceae (10.96\%) and chlorophycated (3.38\%) [NECIB et al. 2013].

\section{CONCLUSIONS AND RECOMMENDATIONS}

The statistical and graphical treatment of the results obtained from the physical and chemical parameters measured in the surface waters of Wadi Bounamoussa shows a degraded water quality. BAHROUN and BOUSNOUBRA [2011] reached this conclusion, which calculated the organic pollution index $(\mathrm{OPI}=1.33)$, indicating the alteration of the waters of our study area whose has a very high organic pollution class. Principal Component Analysis revealed significant links between organic elements and minerals. The statistical study reveals the existence of two group waters: a Wadi Bounamoussa's water characteristic group during the dry season, which has a high mineralization at the mouth due to the high content of chloride ion and electrical conductivity. And a group is characteristic of the Wadi Bounamoussa's water during the rainy season that presents an organic pollution caused by the richness of the environment in organic pollutant (total phosphorus and orthophosphate) thus favouring the phenomenon of eutrophication.
This phenomenon favours an anarchic multiplication of algae and aquatic plants. Agricultural and industrial activities also urban area, are the essential sources of these phosphorus materials, so preserving water resources become imperative in the face of the degradation of these aquatic ecosystems and recommend the establishment of wastewater treatment plants. Therefore, we recommend also an urgent control measures and effluent treatment.

\section{REFERENCES}

Attoui B., Toumi N., Messaoudi S., Benrabah S. 2016. Degradation of water quality: the case of plain west of Annaba (northeast Algeria). Journal of Water and Land Development. No. 31 p. 3-10.

BAHroun S., Bousnoubra H. 2011. Évaluation de l'indice de pollution organique dans les eaux naturelles cas de la région d'El Tarf (Nord-Est Algerien) [Evaluation of the index of organic pollution in natural waters the cases in the region of El-Tarf (Algerian Northeast)]. Larhyss Journal. No. 9 p. 171-178.

Benrabah S., Attoui B., Hannouche M. 2016. Characterization of groundwater quality destined for drinking water supply of Khenchela City (eastern Algeria). Journal of Water and Land Development. No. 30 p. 13-20.

BoukHNOUNA S. 2008. Impact de l'Oued Bounamoussa sur la qualité des eaux de la nappe alluviale superficielle 
d'El Asfour (wilaya d'El Tarf) [Impact of the wadi Bounamoussa on the water quality of the aquifer superficial alluvial of El-Asfour (El-Tarf City)]. MSc thesis. Annaba University pp. 120.

Haridi A., TAammallah F.Z., Ziouch O.R., Ounissi M. 2012. Le phosphore dissous dans la rivière-estuaire du Mafrag: Répartition et niveaux de concentrations [Phosphorus dissolved in the Mafrag estuary: Distribution and concentration levels]. Nature et Technologie. No. 7 p. 102-108.

HaRrat N., ACHOUR S. 2010. Pollution physico-chimique des eaux de barrage de la region d'El Tarf. Impact sur la chloration [Pollution physico-chemical waters of dam from the region of El-Tarf, impact on the chlorination]. Larhyss Journal. ISSN 1112-3680. No. 8 p. 47-54.

ILNICKI P. 2014. Emissions of nitrogen and phosphorus into rivers from agricultural land selected controversial issues. Journal of Water and Land Development. No. 23 p. 31-39.

KHEIREDDINE O. 2012. Contribution à l'étude de la fertilisation des terres agricoles sur la proliferation du phytoplanctan (Oued Bounamoussa) [Contribution to the study of the impact of the fertilization of agricultural land on the proliferation of phytoplankton (Wadi Bounamoussa)]. MSc thesis. Annaba University pp. 140.

Khellou M. 2012. Flux de l'azote et du phosphore minéraux à l'embouchure de l'Oued Seybouse [Flow of the nitrogen and phosphorus minerals to the mouth of the
Wadi Seybouse]. MSc thesis. Annaba University pp. 123.

KHERIFI W. 2016. Study of the influence of the physicochemical parameters on microbial abundance in various ambient conditions. Water Resources. Vol. 43 Iss. 3 p. $564-558$.

LABAR S. 2003. Contribution à l'identification des aires inondables et qualité physico-chimiques des eaux stagnantes temporaires dans la vallée de la Mafragh «Extrême Nord Est Algérien» [Contribution to the identification of flood-prone areas and the physicochemical quality of temporary stagnant waters in the Mafragh valley «Extreme North East Algeria»]. MSc thesis. Annaba University pp. 131.

Necib A., Rezig H., Boughediri L. 2013. La bio-indication de la pollution aquatique par les microalgues (Cas de l'Oued "Bounamoussa" et du Lac des "Oiseaux") [The bio-indication of aquatic pollution by the micro-algae case of the wadi Bounamoussa and the lake of birds]. Synthèse: Revue des Sciences et de la Technologie. Vol. 27 p. $6-14$.

Rodier J., Legube B., Merlet N., Brunet R. 2009. L'analyse de l'eau [The analysis of the water]. $9^{\text {th }}$ ed. Paris. Dunod. ISBN 2100072463 pp. 1600.

Semaoune M. 2008. Comparative study of aeration by the aeration and destratification guidelines on environmenttal inspection systems for Mediterranean area. MAP Technical report pp. 149.

\section{Soumaya BOUSSAHA, Aziz LAIFA}

\section{Jakość wód epizodycznej rzeki Bounamoussa w północnowschodniej Algierii: Statystyczna analiza wybranych parametrów fizycznych i chemicznych}

\section{STRESZCZENIE}

Odpady stwarzają obecnie rosnące zagrożenie dla środowisk, do których trafiają. Tak jest w przypadku wód w coraz większym stopniu zasilanych substancjami nieorganicznymi i materią organiczną, która może zawierać patogeny stanowiące zagrożenie środowiska. Realizowane w tym kontekście badania dotyczą zanieczyszczenia wód powierzchniowych epizodycznej rzeki Bounamoussa w północnowschodniej Algierii. Badania obejmowały analizę fizycznych i chemicznych parametrów wód takich jak: temperatura $(T), \mathrm{pH}$, przewodnictwo elektrolityczne $(E C)$, stężenie jonów chlorkowych $\left(\mathrm{Cl}^{-}\right)$, chemiczne zapotrzebowanie na tlen (COD), zasadowość (TAC), całkowita twardość $(\mathrm{TH})$, jonów fosforanowych $\left(\mathrm{PO}_{4}{ }^{3-}\right)$ i fosforu ogólnego $\left(\mathrm{P}_{\text {tot }}\right)$ mierzonych wzdłuż biegu rzeki od października 2013 do lipca 2014 r. Wody do analiz pobierano z dziesięciu stanowisk, co trzy miesiące.

W celu ustalenia zależności pomiędzy różnymi parametrami fizycznymi i chemicznymi i lepszej oceny oddziaływań antropogenicznych na jakość wód rzeki przeprowadzono analizę statystyczną metodą głównych składowych (PCA). Analiza ta ujawniła dwa gradienty. Pierwszy odzwierciedla eutrofizację wywołaną dostawą nawozów z rolnictwa i intensywnego chowu zwierząt; drugi opisuje mineralizację wód, która przejawia się dużym stężeniem chlorków i dużym przewodnictwem. Analiza PCA pozwoliła ponadto wyodrębnić stanowiska według ich właściwości fizycznych i chemicznych. Wyniki badań umożliwiły także wykazanie sezonowej zmienności analizowanych parametrów.

Słowa kluczowe: eutrofizacja, mineralizacja, parametry fizyczne i chemiczne, rzeka epizodyczna Bounamoussa, wody powierzchniowe 